\title{
The Rise and Fall of a Great American City: Gary, Indiana
}

\author{
Chloé Dotson and Nihal Perera
}

Built for permanency, at the dawn of the twentieth century in the United States, Gary, Indiana was considered the "City of the Century" (O’Hara, 2011). James Lane (1978) calls it the beacon of American planning. Located in the outskirts of Chicago, on the south shore of Lake Michigan, the city was built at the height of industrialism, within extant American social, cultural, and institutional values and standards. Built from scrap, the capitalist industrial utopia stood for inevitable progress, unrestrained production and capital accumulation, unconstrained growth and expansion, and ever-expanding consumption. Gary, thus, displayed American exceptionalism and the power of the United States.

It was nicknamed the Magic City (O'Hara, 2011): U.S. Steel Gary Works was the magician and Gary was the trick. The planning and building of Gary was shaped by thee major streams of influence: (1) the extant social, economic, and cultural ideologies of the time; (2) lessons from the successes and failures of previous industrial cities; and (3) the Americanization of the society. The former is well expressed in the World Columbian Exposition in 1893, which took place right before Gary was built. It was a monumental declaration of the dominant American ideologies of the time; it both represented and shaped American thinking.

In regard to the second, the closest industrial city that affected the thinking of Gary's producers was George Pullman's sleeping car industry. The planners of Gary took extra care to avoid the repeat of Pullman's predicament (O'Hara, 2011). The planners assumed the inevitability of class conflict and adopted strategies to ensure the continuous production of steel without the interruption of such conflict (Lane (1978).
The third influence, Americanization of the society, is related to the first and served the interests of the second. Producing an aspect of Americanization, the ethnic diversity of the city was institutionalized through the segregation of its population and the educational system.

A century later, Gary is hardly a sought after place to live. It is currently represented by boarded-up homes, vacant lots, abandoned schools, dilapidated housing, and a city government that is unable to provide basic services to remaining inhabitants. Its decline began quite early. By the end of the century, the city that once stood for the American dream and exceptionalism had become one of the most distressed cities with resilient residents (at the formal level), non-apathetic city government, and civil society organizations, like churches, that are unable to provide basic services to the residents. In 1994 the city was labeled the Murder Capital of the United States (Sloan 1994).

More books were written about Gary's bad times than good times; these include the City of the Century (Miller, 1996), The Most American of All American Cities (O'Hara, 2010), Gary's Glen Park (Trafny, 2014), and Gary's West Side (Trafny, 2006). Yet its development and planning models were not well critiqued. Even when critiqued, the critics do not derive many lessons. The planning and development of Gary is not part of the curriculum in almost any planning or development program, even in Indiana. The same can be said about distressed and forgotten cities in the USA; much has been written but where did they go wrong? The studies seem to overlook the causes.

This study is an exposition into the planning and development of Gary with the view of teasing out some explanations for its failure. It 
demonstrates that the seeds of Gary's failure were built into its initial conception, which at first made it a success. First, the company's monopoly on the local economy did not leave room for alternatives that could save Gary when the U.S. Steel Corporation was downsized. Secondly, the pattern of race-, ethnicity-, and class-based institutional and cultural segregation and discrimination on which Gary was founded was a primary cause of subsequent urban chaos, degradation, and abandonment.

This article seeks to explore the rise and ultimate demise of Gary through examining thoroughly this model of development from the perspectives of race, class and capitalist driven principles of planning. Through the collection of primary and secondary documentation, research and face-to face interviews with current and prior long term residents of Gary, it juxtaposes scholarly reports, professional perspectives, multivariate statistical interpretation, and the voices of residents to tell the interlaced stories of Gary, once the highlight city of the United States. Together these stories supported by quantitative research and data will assist in the exploration of the rise, fall and potential future of cities around the World.

\section{Streams of Influence: The Columbian Exposition of 1893 and Pullman}

The Great Chicago Fire of 1871 destroyed a substantial portion of one of the most significant cities of the time, including almost the entire central business district. The ambitious rebuilding effort along with particular investment strategies transformed the city into a major center of production and capital accumulation. The rapid development of industry and technology, the introduction of rail freight systems, the availability and manipulation of capital and labor fueled an unparalleled growth of the city. This monumental transformation in America was deemed a viable atmosphere for an Exposition of the United States. Chicago in 1893 was the perfect time and location to demonstrate the progress and advancements in American society and culture. The Columbian Exposition was a monumental declaration both to the world and the nation of the dominant American ideologies of the time. It presented to the world and the country, the "great nation" that America had become, particularly its technology, industry, economy, educational system, society, and culture.

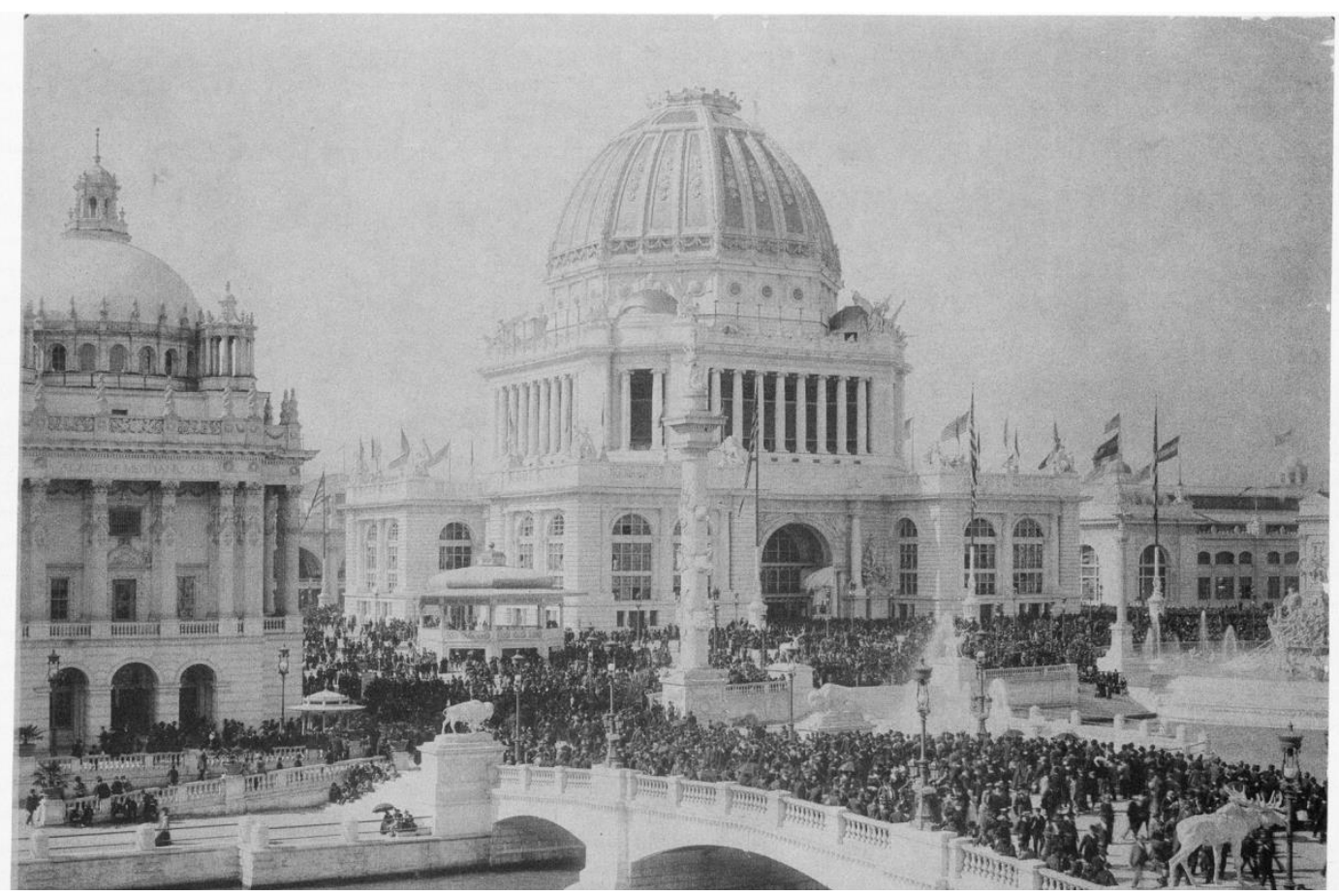

Figure 1: Columbian Exposition: 716,881 people attended the World's Columbian Exposition for "Chicago Day," October 9, 1893. This day commemorated the anniversary of the Great Chicago Fire of 1871 (Rossiter, 1897) 
The Exposition also endowed grandeur and shaped the nation's identity for another century. Planned and designed by eminent figures, it also became a preamble to the pursuit of what became the popular "American Dream." Moreover, the entire planning and construction represented the planning model of the capitalist industrial utopia of the twentieth century.

The renaissance of Chicago was on full display at the World's Columbian Exposition. The Exposition site covered more than 600 acres featuring nearly 200 new buildings constructed in the neoclassical style with canals, lagoons and, with some exceptions, people and cultures from around the world. The grandeur of the Exposition was in its planning and architecture. It was designed by eminent figures such as Frederick Law Olmsted and architect Daniel Burnham, both recognized as "fathers" of their respective fields in America. These "fathers," along with other renowned architects and designers, created a complex of scale and grandeur that far exceeded other world's fairs. Burnham assembled a stunning array of artistic and architectural talent to design the fair's main exhibition buildings on land that landscape architect Frederick Law Olmsted envisioned becoming a public park to challenge Central Park in New York.
The Exposition was a "learn-as-you-walk" installation of events and spectacles that narrated the American form of capitalism and its historical development. It educated the citizens of both the USA and other countries of the exceptionality of Western development, elevated to the level of civilization, and of its new leader: the United States of America. For the first time America was able to successfully boast and valorize its Europe-based philosophies, thus historicizing the USA as the highest stage of Western development, and presented it as the model of universal human development. The total attendance exceeded what would be equivalent to over half the population of the United States at the time.

The approach to the grouping of people into such categories as race, class, and gender were quite stark. The Exposition displayed the progression of the civilized from primitive to most developed (i.e., the White American), primitiveness being attributed to people of color. The visitors were first guided to the Midway, which was a living outdoor-museum of "primitive" human beings, mainly from Africa and Asia. As they walked towards the center, this reference enabled the visitors to measure the progress of "humanity" toward the ideal civilization represented in the White City.

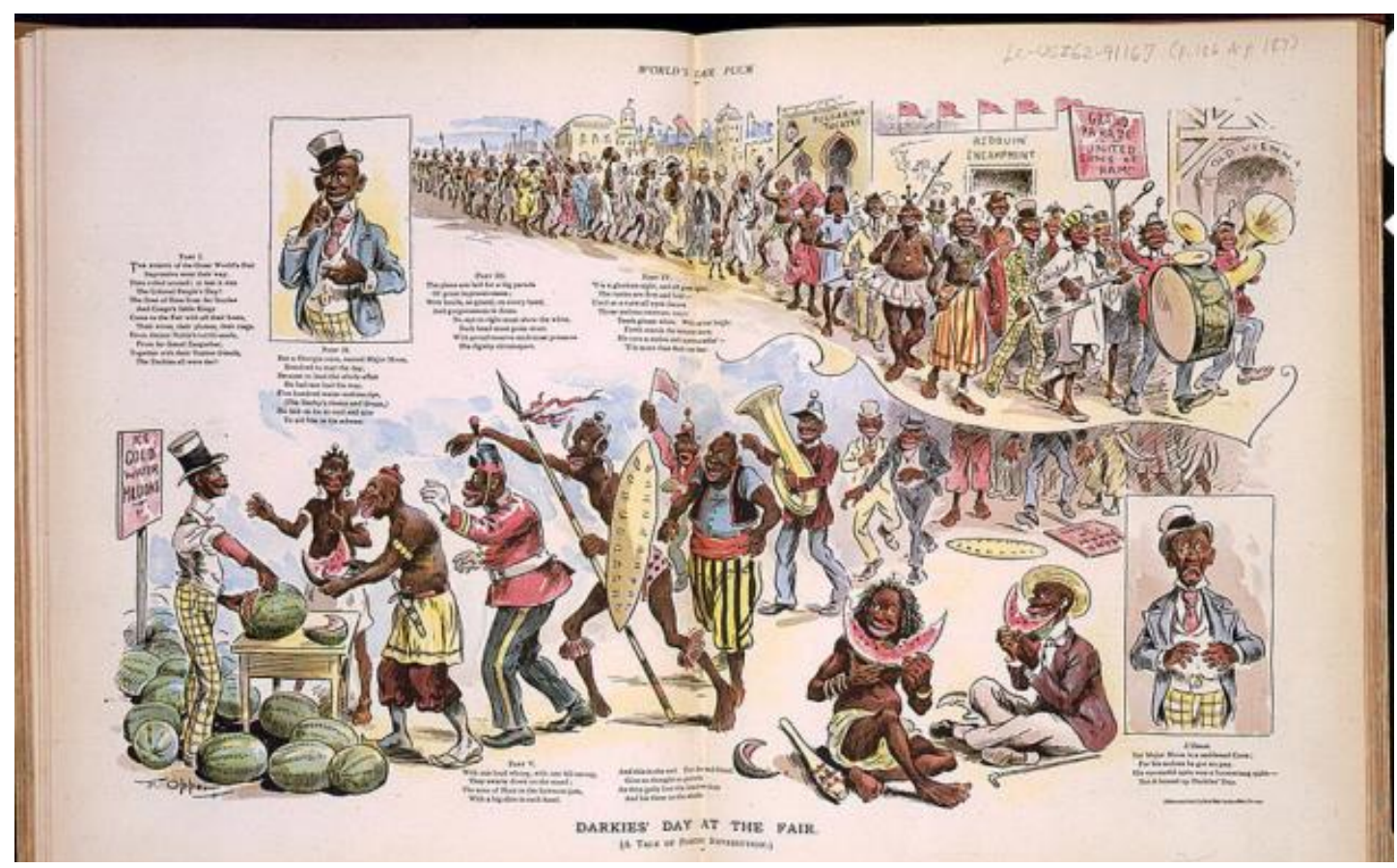

Figure 2: Illustration of African-American participation in "Darkies Day," the day in which people of color were allowed visit the World's Columbian Exposition (Opper, 1893). 
Along the main boardwalk, the visitors were exposed to illustrations of various "cultures" around the world. Built in European classicism, the White City represented Modernity, in terms of capitalism, technology, transportation, and education.

According to Ida B. Wells (Rydell, 1994), the Exposition "was designed to advance the causes of nationalism, imperialism, and consumerism." The racial and ethnic representations served to idealize the "developed [White] American" and perpetuate the hegemonic perception of development as following Europe's historical trajectorydisplaying the deep roots of these ideals in race and ethnicity. Almost all of the sculptors and artists were prominent professionals who were White males. ${ }^{\mathrm{i}}$. The spatial organization and planning not only conveyed the above narrative, but also helped the visitors experience the development trajectory and its race, class, and gender basis.

In addition to displaying and rationalizing the dominant worldview in regard to race, ethnicity, gender, class, and other social stratifications, the Exposition also integrated these into its urban and built form. The visitors were thus provided with an experience of these. These plans integrated the highest possible quality of Americanism.

After the event, the ideologies displayed at the Exposition were exported as plans for cities across America. The achievements were evident in the new forms of architecture, planning, technology, consumption, education, and the "preferred" American lifestyle that emerged in cities.

As evident in the Columbian Exposition, the ideologies of Modernity such as technology, consumerism, industrialism, the American Dream and the ideologies grounded in the geographical planning of the city were founded not only on industrial progress and social power, but also on racial, ethnic, and gender stereotypes and stratifications. As elaborated below in regard to Gary, segregation, perhaps enhanced by the compartmentalized thinking of the time like zoning, was integral to planning.
Class came into planning-thinking due to the potential of class conflict to interrupt capitalist production. The planners of Gary learned the effects of the class conflict from nearby Pullman which had a debilitating conflict. Both Lane (1978) and O'Hara (2011) closely document how the planners of Gary tried to prevent the inevitable industrial, racial, and ethnic conflicts rising from socio-economic inequalities. They opted Gary to survive the ills that had ended industrial utopias of the past; the Pullman experiment being the closest. Developers sought to withstand class strife through strategic and systematic geographical and institutional segregation.

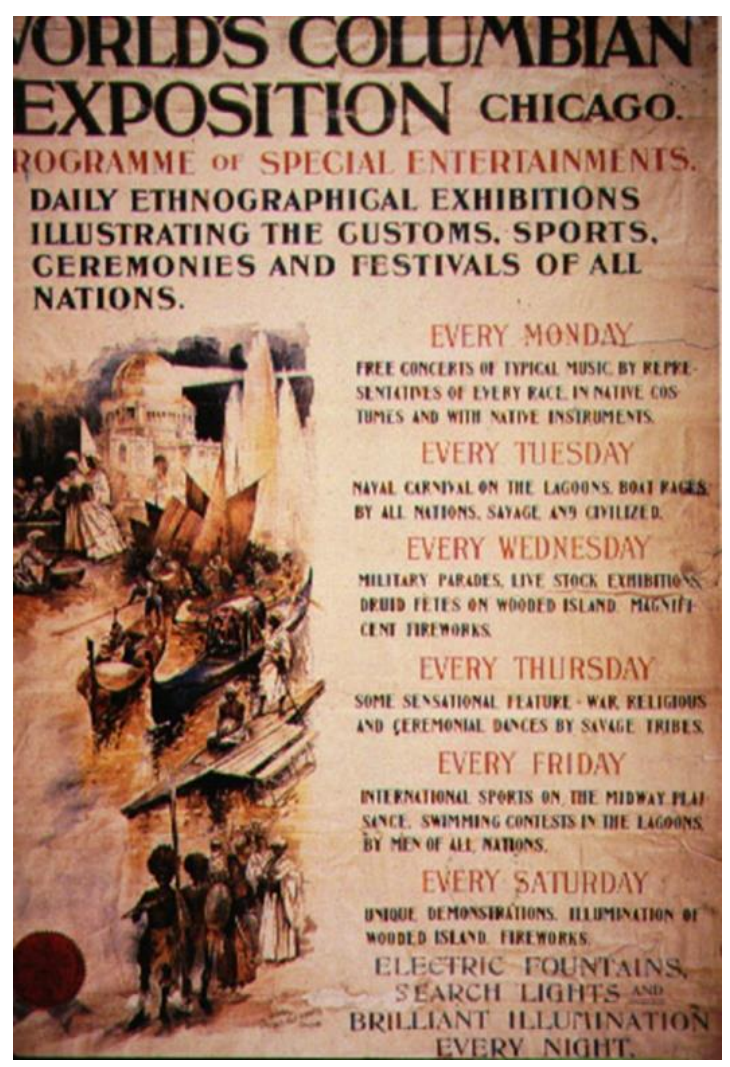

Figure 3: World's Columbian Exposition, Chicago, 1893. National Museum of American History, Smithsonian Institution.

\section{The Creation and Decline of Gary}

It all began in late-19th century Chicago. As an epitome of capitalist development, the city was one of the largest incorporated steel manufacturing zones in the United States. The steel industry in Chicago contained hundreds of companies with nearly 1,000 miles of railroad tracks, and produced two thirds of all American steel (O’Hara, 2011; Lane 1978). 
By the late 1890's, Chicago was capable of producing 4,000 tons of $80 \mathrm{lb}$. steel rails in twenty-four hours (O'Hara, 2011).

The U.S. Steel Corporation's profits exceeded one billion USD, making it the first major integrated corporation in the United States (O'Hara, 2011). Due to the greater demand of its products, the company opted to build a new production facility. U.S. Steel chose to locate the new factory and city (company town) on undeveloped, cheap land outside the city of Chicago. Gary was thus the outcome of the company's economic and geographical expansions.

Thus, U.S. Steel built Gary as its company town. It was founded on the spectacular achievements of American planning and development practices. The building process combined the American culture of conquering, acquiring, taming, and modernizing the frontier. These instincts were carried out by U.S. Steel with the interest of territorial expansion, resource exploitation, and capital accumulation at global, national, and local scales.

As Perera (2004) has argued elsewhere, even when enormous state power was applied in building cities-like Chandigarh and Brasilia-they were developed through a series of negotiations, particularly on scale, location, organization, and form. Beginning with an anonymous site later named Gary, every significant step in the planning process was negotiated, but largely along preestablished lines of industry and social geographic control.

Building a production facility combined with the interest in real estate shaped the company town. A.F. Knotts who was originally commissioned to purchase land for the factory site not only developed the concept of landholding for the enterprise, but also became the head of the land company developed for the purpose. After assembling over 1,500 acres, Knotts approached a Judge in Gary with a proposal:

With the money you plan to set aside for this proposed great plant, and with the talent you have at your command, you can make it a model plant, and a model plant ought to have a model city nearby for its employees (O'Hara, 2011, 88).

Yet, the recent memory and fear of failed industrial experiments made Knotts question the Pullman model. He was uncertain about who should own the houses, infrastructure, and retail establishments all of which were owned by the Pullman Corporation. Instead of a company town, Knotts conceived "a town of free men" (O'hara, 2011, 89). According to O'Hara, "Knotts suggested', that in the new town of Gary, "workmen could be encouraged to buy their own homes and where retail business would be privately owned" (O'Hara, 2011, 89). Gary agreed and Gary Land Company, a subsidiary of U.S. Steel, was created under Knotts with the mission to develop a new city in 1906.

The company purchased 9,000 acres of property along the shore of Lake Michigan for about $\$ 7.2$ million. The land, located in northern Indiana, was near water, rail, iron ore, limestone, and coal (Lane, 1978). Similar to the 600-acre site of the Exposition, this site afforded the new city a tabula rasa to be planned, constructed, and managed.

Within Judeo-Christian values of the time, the environment was to be used for the benefit of the human beings. Hence, environmental implications were hardly considered even in regard to the location of the harbor or blast furnaces. U.S. Steel turned a wilderness area into an industrial city. The existing environment was thus replaced with development, progress, and growth. The grading contractor arrived with his working crew ... to cut down the scrubby trees and tangled vines, level the dunes, fill the sloughs, excavate for the foundations of the harbor and blast furnaces, and fill in the shore of the lake out to the limit allowed by law (Quillen, 99). 


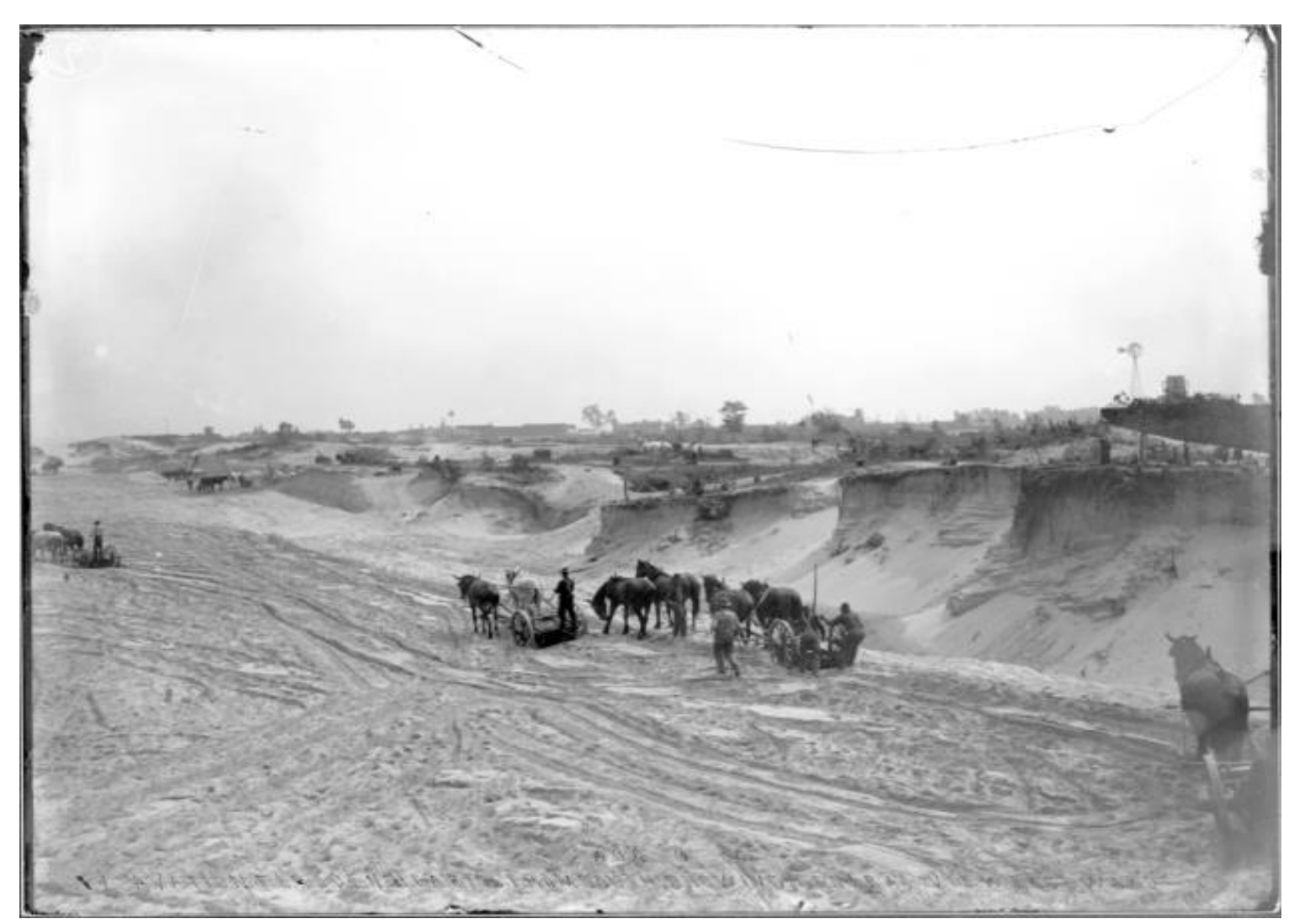

Figure 4: Excavation for open hearth, August, 1906. Source: Calumet Regional Archives, Indiana University Northwest, Gary, Indiana [ID number, CRA-42-100-019])

During the spring of 1905 , construction engineers began making preliminary plans for railroad yards and the plant. Towards the end of the year, project engineer Arthur P.G. Melton began to plan the rest of the city located south of the rerouted Grand Calumet River. The residential area consisted of more than five hundred homes, a forty-room hotel, post office, and school within the first year. The river was engineered into a "moat" separating the mills located on the lakefront and the residential district, in effect, separating the capitalist production (including the executives) from the laborers (Lane, 1978, pg. 28). This social stratification and the hierarchical structure based on class were thus incorporated into the master plan, from the beginning.

Initially, skilled and unskilled construction workers who built the plant and the community populated Gary. A significant percentage of the construction workforce remained in Gary to work in the mill. Many of them were transient in nature and the population had a relatively high turnover rate.
From then on, the population grew very rapidly, from 334 on June 1, 1906, to 10,246 on November 23, $1908^{\mathrm{ii}}$.

The city grew hand in hand with the expansion of U.S. Steel's operations. The company privileged the profit-making, in effect, transforming Gary into an economy, instead of a community. Protecting the economy it built, U.S. Steel also prevented its diversification by resisting the entry of other industries (Mohl and Neil, 1974). Yet, the city depended on the company for its economy and identity. People thus continued to depend on an economy that was driven by U.S. Steel alone.

As the United States entered World War I in 1914 , the production at U.S. Steel increased to unprecedented levels. Throughout the 1920s, Gary's economic prosperity remained dangerously dependent on a single industry. This condition backfired during the Great Depression when the steel mills cut back production by nearly eighty percent (O'Hara, 2011). Merely a couple of decades after the establishment of the city, workers' hours were 
substantially reduced and many were laid-off from the factory. Many residents had to leave Gary and seek economic opportunities elsewhere. Evidence of severe distress was abundant and optimism for the future of the city had eroded. Unemployment soared, most banks failed, and the city government faced bankruptcy (Lane, 1995). Sentiment that Gary was merely another failed capitalist experiment was becoming increasingly prevalent.

The economic demands of World War II revived the steel industry and pulled Gary out of the depression. However, the same demand for steel did not continue after the war. During the 1960s, the relationship between the steel industry and the communities of Gary became increasingly estranged. Racial segregation and strife, labor problems, industrial pollution, and political corruption earned Gary a national reputation as a troubled town.

Deindustrialization of American cities is well documented. According to Marie Howeland (2010), manufacturing declined in Northeastern and Midwestern cities because the management of these cities chose to relocate to the suburbs, to the south, and ultimately overseas. The same ambitions of capitalism, consumerism, and technology ultimately drove momentum for U.S Steel to seek more efficient means of production. Increase in productivity via technological advances incorporated into industrial development caused the demise of traditional work opportunities for millions of Americans.

Gary, once the heart of American manufacturing and production, and which had defined the attributes of America's Dream and utopian cities less than a century ago, bore the brunt of America's industrial decline. A century later, the Census 2010 reveals Gary's decline: The population, which peaked at 178,320 in 1960 , was less than half $(80,294)$ by 2010 . More than half the city including housing and downtown facilities was thus empty.

The period between 1970 and 2000 saw unprecedented economic shifts resulting in adverse effects on the residing population. The national out-migration of steel production peripheralized Gary economically. The city, which boasted more than 70,000 steel manufacturing jobs in 1970, had only 6,000 in 1980. Gary had become a struggling manufacturing, production, and financial center. During the first decade of the 21st century, Gary lost an additional $22 \%$ of its residents and the city's unemployment rate in February 2012 was $14 \%$. While U.S. Steel still employs about 3,500 (in 2015), the skeletal workforce is a far cry from the amount of people who, during its peak, worked at the Gary Works steel facility.

As the company prevented the diversification of the economy, the decline and downsizing of the steel factory, particularly the mass unemployment caused by this, resulted in race and ethnic riots, violence, distressed depopulation, and business blight. According to Jeremy Rifken (1995, xv),
Redefining opportunities and responsibilities for millions of people in a society absent of mass formal employment is likely to be the single most pressing social issue in the coming century.

\section{Race over Class: The Primary Cause of Decline}

The greatest factor that transformed economic growth for US Steel and the global dispersal of production into a terminal disaster for the people of Gary was the American notion of race and the way in which this trait was incorporated into Gary's planning. The planners of Gary responded not only to the problems of maintaining industrial growth but also to the social and cultural systems of American urban centers.

Similar to the production center for George Pullman's sleeping cars, attempts were made by planners to create a model city through controlling social and cultural conditions, to provide the necessary room for economic growth. With strategic arrangements and the testing that followed, the planners of Gary were able to create an industrial town that was not only a "solution" to the technological problems associated with large-scale industrialization, but also to social and cultural issues associated with it. This "total package" caused adverse effects on the citizens, the least 
accommodated. The company sought to control social chaos through strategic separation of people groups. It separated people according to their body types such as race, ethnicity, and gender to serve the economy it was building.

While diversity could have been an asset, the company opted to use it to divide the working class along racial lines. It used race to balance class, redefining the heterogeneity of Gary's population in terms of race-class stratification. This is not too strange: Modern Western cognition itself is developed through separation. This scientific concept is also used in understanding space, as in rooms in houses with assigned functions and cities mapped in terms of zones. The latter is precisely the strategy the builders used, but in addition to land use categories planners used class and race. This division and discrimination generated conflicts among race and ethnic groups, at times giving rise to violence. Gary not only lost its population and its economic engine, but also commercial, retail, managerial services as well as public amenities, and political-economic stronghold that supports existing infrastructure systems.

The issue maybe more deep. Despite the grand statements it made about America and its exceptionalism, the World's Columbian Exposition also brought to light deep-rooted conflicts in America. African-Americans and women protested over their representation at the fair. For many African-Americans, the Dream City at the Columbian Exposition was a nightmare. They were denied voice and a place for most of their exhibits in the fair's creation; the exhibits had to be approved by an all-White screening committee before display. Equally disturbing were the displays by private companies that ridiculed Blacks.

Even more clearly, the so-called living ethnological exhibits of "primitive" human beings reinforced the impression that Blacks were closer to "savagery" than to "civilization." As the racist underpinnings of the fair's utopian projections became clearer, many African Americans concluded that the World's Columbian Exposition, with its radiant White City at the center, had become the cultural counterpart to lynching that claimed 161 African-American lives in 1892 alone. The label "primitive" attributed to people of color facilitated the justification of geographic and institutional separation of races and repression of people of color in American Cities, specifically at the "City of the Century."

This was also a time when the class conflict was beginning to threaten capitalist interests across the world. The Soviet revolution was yet to come, but the struggle was imminent from the late-nineteenth century. This threat was in the minds of planners; its image was reinforced by the struggles at prior industrial towns such as Pullman. The planners of Gary, following the visionaries, sought to create an urban industrial utopia that could withstand the imminent challenge to capital from labor, particularly the potential chaos this could cause in the city.

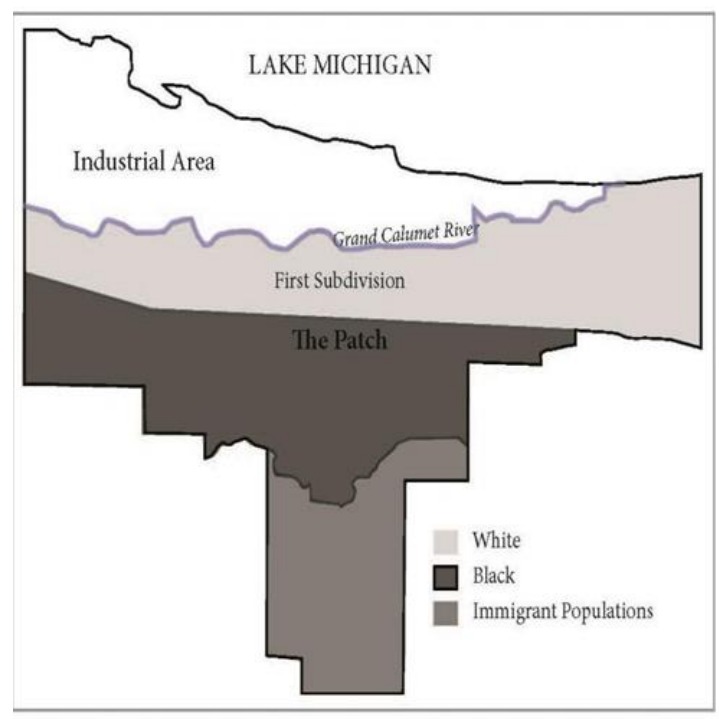

Figure 5: Planned Racial Hierarchy and Class division in Gary (Hurley, 1995)

The city plan undermined the class conflict by superimposing it with race and ethnicity. This was clearly marked in the geography of the city. First the factories were located in the north, bordering Lake Michigan. The adjoining area was reserved for administration and the residences of supervisory staff such as plant foreman and skilled workers; predominately elite classified White Americans (O'hara, 2011). 


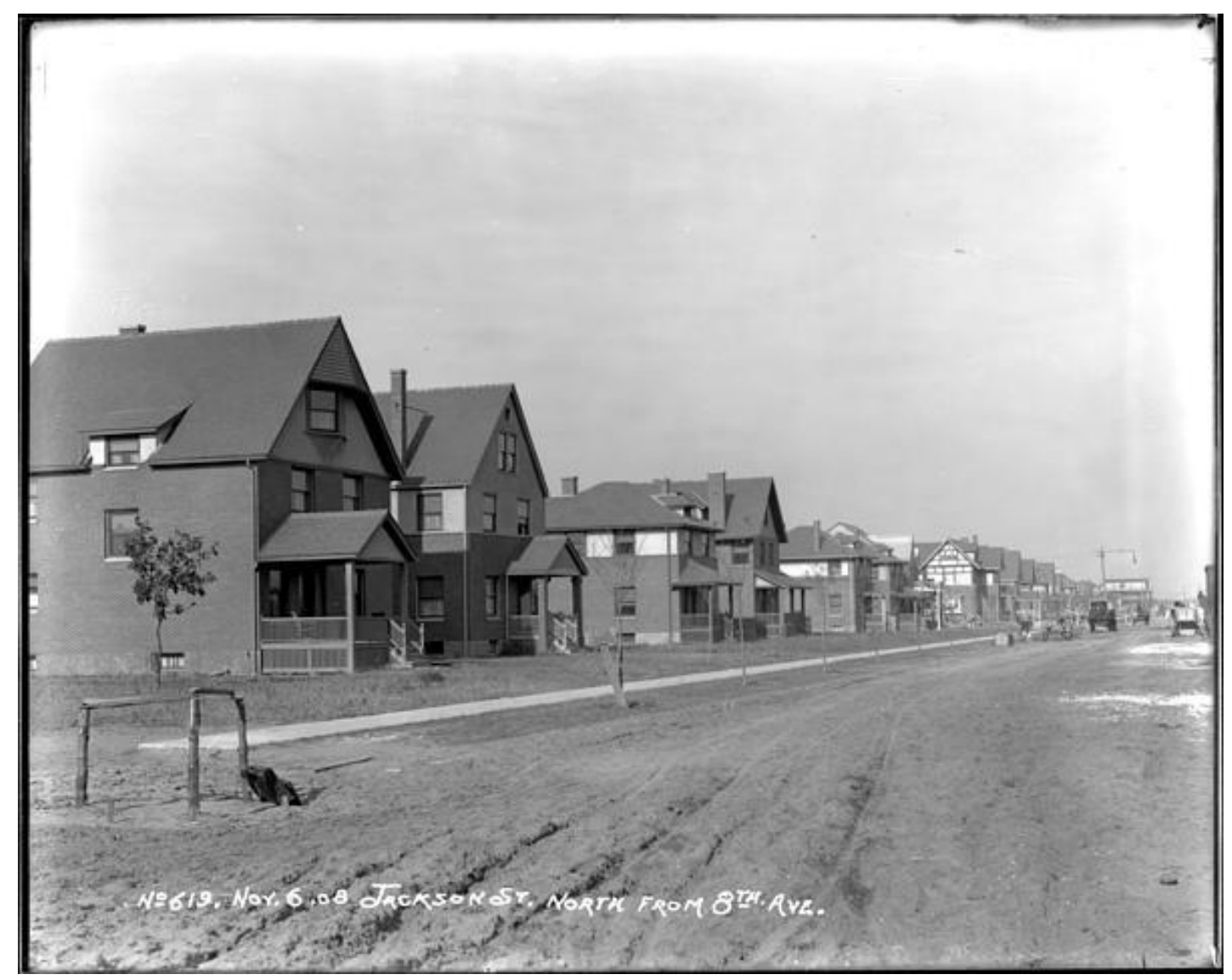

Figure 6: Jackson Street $\mathrm{N}$ from 8th Avenue, November, 1908. Source: Calumet Regional Archives, Indiana University Northwest, Gary, Indiana [ID number, CRA-42-102-125].

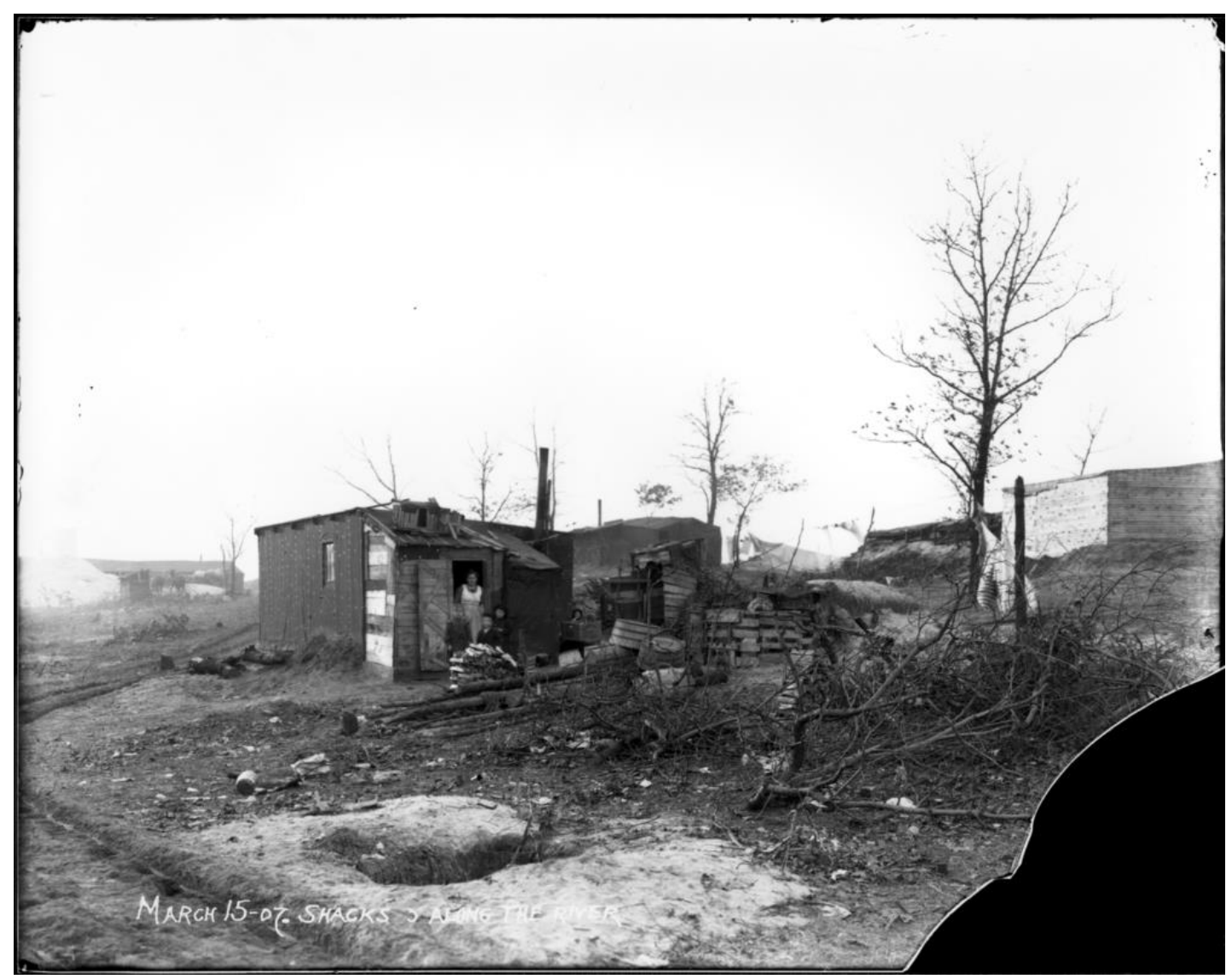

Figure 7: Housing in the 'Patch' Calumet Regional Archives, Indiana University Northwest, Gary, Indiana [ID number, CRA \#41 
The southernmost district occupied by African Americans and low-income immigrants was called the "patch." Later the white immigrants were located further south, but separate from the Blacks. In essence, there were four separate districts: the mills of Gary Works, the First Subdivision, the "Patch," and the immigrant area. Gary was therefore subjected to planned segregation of capital and labor and, within this, the races.

Gary Works was separated from all residences by the rerouted Grand Calumet River. The engineered river was essentially a moat that enables the cutting off of the south in case of social conflict that could potentially hinder progression of Gary Works. Gary Works thus built a fortress on the frontier, reinforcing geographic separation of production and labor by not only the river but also extensive rail lines. This planning produced two strikingly distinct Garys, in terms of residential areas: one neat and clean and the other chaotic.

This social and economic organization of space resonates David Harvey's $(1973,81)$ argument that the accumulation of capital requires:

...the creation of a physical landscape conducive to the organization of production in all of its aspects including the specialized functions of exchange, banking, administration, planning and coordination, and the like, which typically possess a hierarchical structure and a particular form of spatial rationality.

"The creators of Gary ... sought to clearly define, confine, and restrain the spaces of their city" (O’Hara 2011, pg. 85). Beyond Harvey's focus, Gary planners added race and ethnicity. These racial and ethnic divisions were hierarchically organized from north to south, along the main axis: Midway Plaisance. The spatial organization of Gary thus stands for another dimension of American exceptionalism: the construction of race and racial segregation.

In sum, In order to combat the class conflict, U.S. Steel evoked racial difference, laid over the class conflict, and created an environment of 'divide and rule' of the classes. In so doing, it produced its own race- and ethno-scape and conflicts. In order to develop the same, U.S. Steel exercised an insurmountable influence on Gary's social environment, through strategic planning and development methods, thus creating a model American city of the period.

\section{Beyond the Point of No Return: The institutionalization of Racism and Segregation}

From 1910 to 1970 , the city experienced remarkable geographic and demographic transformations. African-American migration from the South, which began as early as 1910 , was greater than anticipated and required more room than assigned in the initial planning of the city. "Like... white immigrants, the black newcomers arrived in the steel city hoping to fulfill economic aspirations and to achieve a new and better life for themselves and their children" (Mohl and Betten, 1950, 26). Yet, according to David Freund (2007, p. 13), "the residential color line remained firm (if shifting) first within the city center itself and then, the suburb." Within this structure, the Whites, both the locals and those of European descent, gained access to the American dream in which millions became homeowners for the first time (Freund, 2007).

The African-American population grew by 1,213 percent during the decade of WWI; this was followed by comparable population explosions in the following decades. The discriminatory practices woven into the fabric of Gary became increasingly threatened by the massive presence of skilled and unskilled African-American industrial-workers and their families. The calculated geographical, racial, and ethnic divides established by the renowned planners of the city were hard to maintain. Yet the temporary integration into immigrant districts did not last long. In the words of Raymond Mohl and Neil Betten (1950, 26; emphasis our's):

Because they were black, they faced persistent problems of discrimination and segregation which white immigrants did not have to contend... The segregation of Gary's population did not develop accidentally out of housing patterns. Rather, 


\begin{abstract}
discrimination and segregation in education, housing, employment, public services, and recreation was established and carried out by the city's white elite - businessmen, bankers, realtors, educators, steel company officials, and local government leaders.
\end{abstract}

Mexicans and African Americans lived sideby-side, but in neighborhoods separated from the White residential areas. Despite the demographic changes and their declining numbers, the classified Whites tried to hold to their geographic isolation from the immigrant settlement (Hurley, 1995). At first, due to learned racist attitudes from early settlement leaders and latter, hostile attitudes developed toward African Americans and Mexicans, eastern and southern European immigrants also opted for segregation. As more classified Whites became homeowners (i.e., after the War) private sector discrimination rapidly created new patterns of metropolitan urban sprawl and geographical segregation of races. These were fed by each other: the marketgenerated fear caused more segregation; along with the segregation, fear increased.
Charles Johnson (1947) and Herman Long (1947) explored links among White people's ideas about race, politics, and geographical property shifts:

Where the factor of decline in property values can be directly linked to Negro occupancy or threaten 'invasion', it is evident that the phenomenon is a psychological one existing in the minds of the White people rather than attributable to the Negro themselves. (Johnson 1947, pg. 6)

A subtle shift in the planning language allowed biological differentiations to be associated with property ownership and privileges (Freund, 2007). Long and Johnson (1947) and Long (1947) explain that it was the large-scale use of restrictive covenants, the vigilance of White neighborhood improvement associations, planning guidelines, and the complicity of both private interests, and public officials that translated White fears into policy, legal precedence, residential subdivisions, and housing equity.

\section{Population by Race from 1930-2000 in Gary, Indiana}

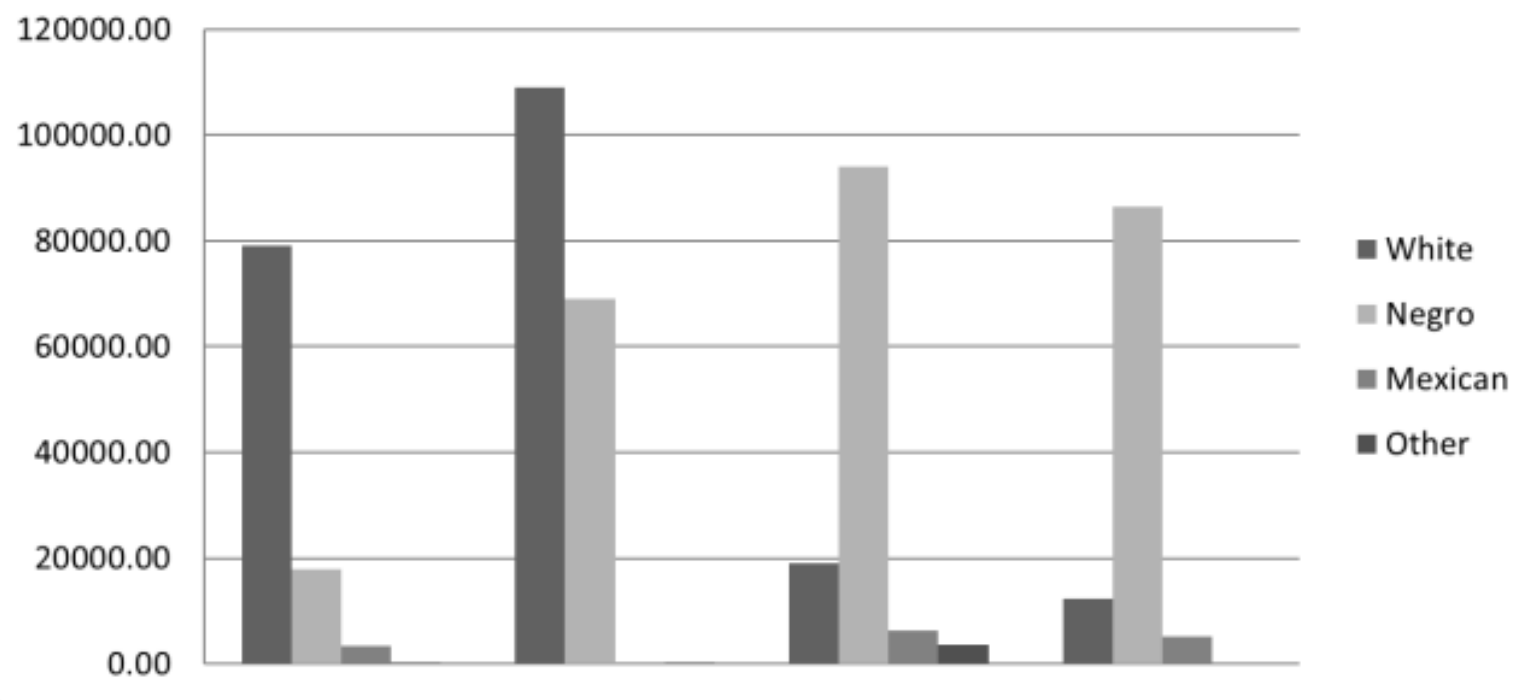

Figure 8: Shifts in the population and its ethnic composition, 1930 to 2000 (Bureau of the Census: United States National Archives and Records Administration, 2005) 
Zoning policies, real-estate and mortgage practices, provided legal instruments and knowledge for homeowners to exclude a wide range of developments and populations. By creating a hierarchy of zones, planners segregated not only the land uses but also citizens. Zoning statutes and land-use practices provided suburban communities with the authority to exclude entire classes of people, and to enforce a social-scientific logic that upheld Whites' racial preferences. Along with restrictive convents, federal appraisers, White real-estate developers who had monopolized the business deemed property unsalable to African Americans in the far larger and federally secured market for "White property." According to Freund, property was allocated to the privileged. This facilitated their 'escape' to new suburban development, hindering the mobility for minority populations, serving segregation through discriminatory urban planning practices, and causing deprivations for the remaining Black population through redlining, zoning, restrictive covenants, and other forms, simultaneously (Freund, 2007).

As the influx of immigrants and migrants increased, initial spatial and institutional segregation began to weaken. The planned geographical racial and ethnic lines of isolation began to fail. The dramatic increase of the African American population and the assimilation of European immigrants resulted in the spilling over of one classified race into other areas, both geographically and institutionally.

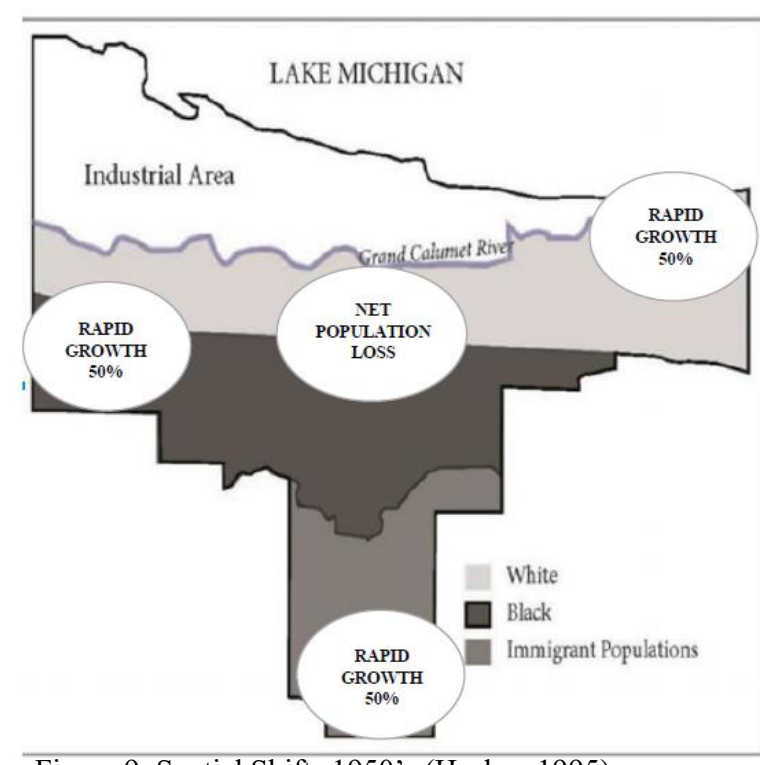

As classified Whites, the immigrants (i.e., the Poles, Serbs, Greeks, Russians, and others) moved further south constructing homogeneous ethnic enclaves such as the Glen Park section of the city (Hurley, 1995). Since 1950, the downtown central business district saw large amounts of net population loss, but Glen Park, Miller, and other surrounding racially homogenous White communities saw over $50 \%$ of population growth. Further escalating "White flight," the classifiedWhites not only moved out of Gary to what became Merrillville and Hobart, but also transformed these into independent incorporated urban areas, i.e, separate towns.

The decline of the city became evident from the 1960s. The White population dramatically dropped from 108,980 in 1960 to 18,995 by 1990. During the same period, the proportion of the White population plummeted from 61 to 16.3 percent and the proportion of African Americans rose from 38.7 to over 80 percent.

The majority of retail and commercial services, investments, and jobs followed the more affluent and privileged population. Downtown was directly affected by businesses following the customer's mass migration south. Stores such as Gordon's, Goldblatt's, JC Penney's, Sears, Kay Jewelers, and countless others eventually relocated in the nearby cities of Merrillville and Hobart. This caused the reduction of retail jobs by more than one-third; simultaneously decreasing the cities once viable tax base. As Gary became increasingly poor and Black, Merrillville and Hobart became richer White bastions.

Politics changed the rest. Gary was a stronghold of the Democratic Party, but its nature changed in 1967. In O'Hara's words,

In the traditionally Democratic city of Gary, incumbent A. Martin Katz had received the endorsement of both Democratic Party and the United Steelworkers support that normally would have guaranteed him victory.

Instead of supporting Katz in the primary, the majority of African-American voters supported the "Black candidate" Richard Gordon Hatcher. The primary campaign between Katz and Hatcher was fierce and

Figure 9: Spatial Shifts 1950’s (Hurley, 1995) 
highly racialized (O'Hara, 2011, pg. 137). Gary-resident Gildon proclaimed: "We were proud to have an African-American mayor." According to Edwards, "We loved our Mayor. We thought he could do great things for our city...".

White flight to nearby suburbs had already begun prior to the 1950's, but Hatcher's election as Mayor and his perceived confrontational style accelerated the exodus considerably. A current resident in the city recalls,

I know the Whites had been moving out, but it seemed like when he was elected, as he moves his hands quickly slapping them across each other in a swift motion] they all left ... .

In Gildon‘s (2012) words:

When the first black Mayor came, we was [sic] so proud. Then fights and battles started. Then it slowly started to depreciate. Stores started closing up, people started packing up ... A lot of things have been torn down and never rebuilt. I use to be able to leave one job today and get another job next week.

The election of Hatchet gave the idea that the racial segregation would break down. Yet, the prospect of sharing a neighborhood, especially in a city planned and constructed on the institutional premise of racial segregation and hierarchy, was viewed by many as undermining the very dream for which people had worked and fought hard. According to O'Hara (2011, pg. 139),

The notion that the barriers of racial separation had broken down and integration of neighborhoods was unstoppable drove many [more] of Gary's White residents to look for housing in surrounding communities.

The market, especially the increase in land prices of new White settlements, also helped segregation. This well illustrates social injustice constructed through ordinary market mechanisms that Harvey (1976) highlights. Eugene Kirtland, witnessing the influx of African Americans into the historically homogeneous White community of Glen Park, stated, "...there could never be, in his mind, any kind of compromise because any integration would undermine the utopian nature of Glen Park" (O’Hara, 2000, pg. 139).

The Great Migration of African Americans and the immigration of east and south Europeans within planned geographical and institutional segregation and discrimination, coupled with deliberate separation of capital, labor, and races was a preamble to civil conflict and degradation of the city.

Modern America was built on this racial platform. White ethnocentrism and its constituent ethnic hierarchy were so institutionalized, both spatially and socially, disenfranchising merely based on their physical appearance. Although it may seem that way on plans, development is not simply built upon the physical manipulation of the natural environment, but involves the assignment of spaces and spatial subjectivities to support the pre-determined order of privilege and profit and the trajectory of its progression. As people made Gary their home, they entered into this predetermined and planned class-infused racial hierarchy regulated by the agencies that provided employment, recreation, commerce, and entertainment. Ironically, the same agencies which constructed this structure, and the same social agents who enjoyed its privileges, abandoned Gary, leaving behind the unprivileged and the poor.

\section{Americanization: Segregation, and Bifurcating the Community}

The materialization of a new America displayed at the Columbian Exposition requires the practice and, more importantly, the internalization of above values by the inhabitants. It was therefore crucial for the state, capital, and cultural institutions to socialize the subjects into the same. Within the United States, this involved educating extant and future citizens. The school systems played a crucial role in assimilating diverse citizens and immigrants into the socio-economic, institutional, and cultural value structure of the American Dream.

Throughout the first half of the century, Gary was a testing ground for the Americanization of migrants from the southern regions and 
immigrants mainly from Europe. Regardless of why they came to Gary and their own backgrounds, the attempt was to socialize them into American values that were being constructed. In O'Hara's $(2011,62)$ words, "new models of social reform, urban education, religious integration and Americanization could be tried, refined, perfected [in Gary] and eventually exported to other industrial cities." As evident in this discussion, Americanization was assimilation; there is (at least, was) very little tolerance for difference in its structure.

Assimilation was carried out through the education of social and cultural institutions, particularly their structures, hierarchies, and economic and social expectations. Many of the city's institutions such as schools, churches, workplaces, settlement houses, political systems, and newspapers worked hard to Americanize immigrant steelworkers and their families as soon as possible (O'Hara, 2011). Gary's nationally famous "work-study-play" or "platoon school" system, implemented by long-term school superintendent William A. Wirt, sought to 'Americanize' immigrant children and prepare them for industrial work. Children were seen as future U.S. Steel workers. Institutions such as educational and employment centers built consciousness and pride in various heritages of immigrants and encouraged inter-ethnic cooperation and understanding (Lane, 1995). Nonetheless, racial and ethnic supremacy and inferiority was at the heart of this structure.

The assimilation of European immigrants and African-American migrants were carried out in two different ways. Generations of people were systematically assimilated into different communities that made up America, but the makeup of that structure has changed over time. For White Americans, even in the early twentieth century, the Irish and the Jews were socially comparable to Negroes; however, within a couple of decades they became "White." Although they were not treated equally, the construction of a White race was evident in the way they and new Europeanimmigrants were assimilated, particularly treating them as more privileged than the African Americans and other people of color.
The assimilation of African Americans was carried out through their separation from the general public, which did not include African Americans. In addition to the allocation of The Patch for habitation, classes, team sports, and other activities also increased segregation of classified races. Gary School Superintendent Wirt believed that it was only justice to segregate the African-American children (in Cohen, 2000). Lane $(1978,144)$ states, "This move of the school board which has always been included in its plans has met with the favor of the better element of the Negro residents of this city." According to Lane, "There is naturally a feeling between the Negro and the Whites in the lower grades and we are sure the colored children will be better cared for in schools of their own. They will take pride in their work and will consequently get better grades" (1978, pg.144).

Although the Baptist Church housed thirty children in 1909, many African-American children were educated in the basements of other facilities. The Baptist Church to which the African-American students were relegated was in relative proximity to a saloon. This was not a concern. The Gary Daily Tribune alluded to the perception that having AfricanAmerican teachers would enable the AfricanAmerican children to do better in school and get better grades. This would totally segregate African-American schools. The newspaper argued: "It is certain that as soon as they become accustomed to the new situation the [African-American] school children will become friendly rivals of the other children in their school work" (in Cohen, 1990, pg. 8). Race consciousness was thus introduced into the minds of kids as they began schooling.

African Americans were assimilated, but as inferior Others. This ambivalence cost Gary a lot. According to John Bodnar (2004), Gary is an example of how utopian ideals, rooted in the process of industrialization, resulted in racial segregation and of the demise of the American standards associated with industrial growth.

It was ambiguous for African Americans too. They (somewhat similar to the classified Whites who were seeking employment) migrated to northern U.S. cities in order to 
escape racial, economic, and ethnic oppression and violence in the South. Migration did help them escape the South and many found employment too. Yet they were met with discrimination of a different kind. The migrants, both as individuals and families, encountered familiar social and cultural barriers upon arriving in the "promised land."

Americanization, therefore, involved the transmission of cultural values, particularly the (White-American) mainstream notions of race, ethnicity, and race relations, which were clearly defined and reinvigorated at the Exposition of 1893 and transmitted in the organization of space in Gary. In practice, the Americanization produced separate White and color societies. The divided and hierarchical society so produced would guarantee the birthrights - or the caste-system - of the United States, reinforcing a new Whitecolored divide. This was not limited to Gary; the results of these social ills are illustrated in present demographic composition of most post-industrial cities.

\section{The American City: Capitalist or Race Driven?}

Gary represents the rise and fall of a wellplanned and calculated attempt to create an industrial utopia in America at the dawn of the twentieth century. Built on virgin land, manipulating both the natural and social environments, Gary was developed by a leading steel producer as a place with limitless opportunity. It embodies capitalists' desire for non-stop production and the strategies used at the time. It was not a mistake: Gary fulfilled the vision of its creators and still produces as much steel, although the factory is downsized and the number of workers reduced in the name of efficiency which largely means the ability to extract more surplus value.

It is the city of ordinary people, or the subjects, that fell into disarray. Once a promised land - a place of jobs and future for people from the South as well as "underdeveloped" European countries - it is currently represented in boarded-up homes, vacant lots, dilapidated housing, abandoned schools, business blight, liquor shops, unemployment, ethnic riots, violence, and food deserts.
Divide and rule was deliberate. It was very much present since the colonial period (also in European colonies elsewhere); but the earlytwentieth century American form of divide and rule was very specific. The planners of Gary accepted the inevitability of the class conflict and planned to ensure that this conflict would not interrupt continuous production at the steel factory. The management and the planners blatantly used race to overcome (or confuse) the class conflict; this was achieved through the spatialization of the then predominant American worldview based on the supremacy of the White race. The social stratification and the hierarchical structure based on class were incorporated into the master plan, from the beginning. This was very clearly drawn on the ground.

The effects of race-based planning on the city and its population have been devastating. Within six decades of conception, the city began to decline; towards the end of the century, the "city of the Century" was known as the "Murder Capital" of the United States.

The USA is a legalistic country that exports the rule of law to the world (Chua 2003). The USA also has laws to protect even research subjects from researchers who might conduct a survey to help the subjects themselves. Yet, as this study demonstrates, during peaceful periods, ordinary people are most vulnerable to the system itself (i.e., the larger politicaleconomy of which they are subjects and the recipients of what the planning system provides). Gary's failure did not come from any outside, but was built into the conception of the company town which supported the latter's success. Gary's decline reveals the shortcomings of institutionalized development and planning principles displayed, rationalized, and propagated at the Exposition which, in their reinvigorated forms, acted as the backbone of planning and development ideologies in America.

We have not found any evidence to suggest that the destruction of the city was deliberate, or even the planners saw it coming. Yet as the planners focused on maintaining production and the economy, the long- and medium-term social outcomes were out of their sight ${ }^{\mathrm{iii}}$. 
The study reveals the two most significant aspects of the conception of the city that caused its demise. First, U.S. Steel overcame, or managed, the potential class conflict by separating the races and creating potential conflict between them. In this, they invigorated and redefined the unique race classification and conflict in America. This construction of race too was not unique to Gary; America as a whole is struggling with it. The strategy exploded beyond the control of the city managers, highlighting a national issue of injustice.

The history of race and industrialism in the United States cannot be separated. As much as one cannot talk about an industrial revolution in Western Europe without references to colonialism, and the huge resources, particularly labor, it drew from the colonies, and the early development of the US economy without slavery, the twentieth-century industrialism of the USA cannot be explained without race-based discrimination and racism.

Second issue is the company monopoly. When the city began to decline, there were no alternatives available for the community; the company did not leave room for any other enterprise or significant economic activity outside competition. Although Gary was built as a town, at a larger scale than simply a production facility, U.S. Steel continued to monopolize the economy and authority of the city, including the use of land. From a planning and development standpoint, this prevented the diversification of the economic base, preventing the growth of other significant economic activities that would support Gary's economy when it began declining.
It may be justified in some ways for the company to monopolize the economy as it built the whole settlement.

However, as America urbanized through company towns, the whole urban system was in jeopardy from the beginning. This became amply evident in the decline of most cities in America, especially from the late-1970s. Although this is a planning failure, it is hard to imagine that the planners ever foresaw this future.

As much as it reveals, the study also raises more questions: First, how can planners learn from Gary, the most American of American Cities? What should planners unlearn to prevent the perpetuation of self-destructive planning principles? Most of all, is it not time for development experts and planners to be honest about classism, racism, and other biases? Should planners examine the roots of planning as many of the ideologies that support contemporary planning stem from 19th Century American exceptionalism that is devastating for millions of Americans?

\section{Acknowledgments}

We wish to thank Associate Professor of Architecture at Ball State University, Olon Dotson whose interest in what he calls the Fourth World in the USA, understandings of Gary, and the PhD work on that city have inspired us and for his constant revealing of the significance of race in the production of space in the USA. This article is built upon Chloe Dotson's (2013) master's thesis on Gary.

\section{REFERENCES}

Abbott, J. R., and Louis Sullivan, (2000) Architectural Modernism, and the Creation of Democratic Space, American Sociologist. http://www.accessmylibrary.com/coms2/summary_0286-663750_ITM

Badger, R. (1979) The Great American Fair: The World's Columbian Exposition and American Culture. Chicago: Nelson-Hall, 1979.

Bureau of the Census. (2013) United States National Archives and Records Administration. N.p., 19302000. Web. 15 Sept. 2013.

Calumet Regional Archives, Indiana University Northwest, Gary, Indiana

Chicago. World's Columbian Exposition. (1893) 1893.World's Columbian Exposition, 1893: Official 
Catalogue. Chicago: Conkey, 1893.

Chua, Amy (2003) World on Fire: How Exporting Free Market Democracy Breeds Ethnic Hatred and Global Instability. New York: Doubleday

Cohen, R. (1990). Children of the Mill: Schooling and Society in Gary, Indiana, 1906-1960. Bloomington: Indiana University Press.

Cohen, R and Mohl, R. (1979). The Paradox of Progressive Education: The Gary Plan and Urban Schooling. Port Washington, NY: Kennikat Press.

Dotson, Chloe (2013). Planning in the Absence of Development: A Case Study of Gary, Indiana. Ball State University. Muncie, Indiana

Douglas, Fredrick \&Wells, Ida, The Reason Why the Colored merican is Not in the Worlds Columbian Exposition. No Imprint. Beineeke Library, Yale University.

Freund, D. (2007). Colored Property: State and Police of White Racial Politics in Suburban American. London: Chicago Press,

Harvey, D. (1973). Social Justice and the City. Baltimore. MD: Johns Hopkins University Press, 1973.

Harvey, D. (1990). The Condition of Postmodernity. Malden, MA: Blackwell Publishers

Harvey, D. (2012). Spaces of Capital. New York, NY: Routledge

Hurley, A. (1995). Environmental Inequalities: Class, Race, and Industrial Pollution in Gary, Indiana, 1945-80, Chapel Hill, NC: University of North Carolina Press.

Hurley, A. (1995). Environmental Inequalities: Class Race and Industrial Pollution in Gary Indiana 19451980. The University of North Carolina Press.

Lane, J. (1978). City of the Century: A History of Gary, Indiana, Bloomington: Indiana University Press.

Lane, J. (1992). The Protestant Experience in Gary, Indiana, (1906-1975). Knoxville: University of Tennessee Press.

Logan, John R., and Harvey L. Molotch. (1987). Urban Fortunes: The Political Economy of Place. Berkeley: University of California Press.

Miller, Donald. (1996). City of the Century. New York City, New York. Simon \& Schuster

Mohl, , R. A., and Betten, N. (1974). Paternalism and pluralism: Immigrants and Social welfare in Gary, Indiana, 1906-1940. Lawrence: University of Kansas.

Mohl, R., and Betten, N. (1986). Steel City: Urban and Ethnic Patterns in Gary, Indiana, 1906-1950. New York: Holmes and Meier Publishers.

Opper, Frederick Burr, 1857-1937 “Darkies Day at the Fair.” Puck, 1893 Aug. 21, pp. 186-187. Collection of the Library of Congress

O'Hara, P. (2007). The end of utopia: imagining the rise and fall of Gary Indiana. Doctoral dissertation, Michigan University.

O’Hara, P. (2011). Gary, The Most American of All American Cities. Indiana: Indiana University Press.

O'Hara, P. (2010). The Very Model of Urban Decay: Outsides narratives of industry and urban decline in Gary, Indiana. Journal of Urban History, DOI: 10.1177/0096144210391613

Perera, N. (2004) 'Contesting visions: Hybridity, liminality, and authorship of the Chandigarh $\square$ plan,' 
Planning Perspectives, 19, 2: 179-203.

Rifken, J. (1995). The End of Work. New York City, New York: Putnam Publishing Group.

Rossiter, Johnson. A History of the World's Columbian Exposition held in Chicago 1893; by authority of the Board of Directors. New York, D. Appleton \& Company, Cornell Univeristy Library, 1897.

Rydell, Robert W. All the World's a Fair: Visions of Empire at America's International Expositions, 18761916. Chicago: University of Chicago Press, 1984.

Sloan, Paul (1994). Gary Takes Over as Murder Capital of U.S. Chicago Tribune Jan 3. Retrieved from: http://articles.chicagotribune.com/1994-01-03/news/9401030009_1_murder-rate-killingsunemployment-rate, retrived on November 23, 2016.

World's Columbian Exposition, Chicago, 1893. National Museum of American History, Smithsonian Institution.

Trafny, John. (2006) Gary's West Side. Charleston SC, Chicago, IL, Portsmouth HN and San Francisco, CA. Arcadia Printing

\footnotetext{
${ }^{\mathrm{i}}$ Major outdoor sculptures included works by Augustus Saint-Gaudens, Frederick MacMonnies, and Daniel Chester French. The major buildings and their architects included Administration, by Richard Morris Hunt; Agriculture, by Charles McKim, William Mead, and Stanford White; Electricity, by Henry Van Brunt and Frank Howe; Horticulture, by William L. Jenney and William B. Mundie; Fisheries, by Henry Ives Cobb; Machinery Hall, by Robert Peabody and John Stearns; Manufactures and Liberal Arts, by George B. Post; Mines and Mining, by Solon Beman; and Transportation, by Dankmar Adler and Louis Sullivan. (Abbott, 2000)

ii On June 1,1906 , the population was 334 ; by January 1 , 1907, it was 5,550 ; by January 1 , 1908, it was about 8,000; and by November 23, 1908, it was 10,246. The population figures for November 23, 1908 are based on a rough census taken by the Gary Land Company. (Quillen,162)

iii Many planners and planning educators tend to focus on what they call practical as opposed to theory. In so doing, they overlook long-term and broader implications. Gary is a good example.
} 